\title{
SSCP Analysis
}

National Cancer Institute

\section{Source}

National Cancer Institute. SSCP Analysis. NCI Thesaurus. Code C19229.

A procedure used to demonstrate nucleotide sequence variations that occur in the same region of DNA between individuals within a species, or between alleles in an individual to detect mutations in various genes, such as oncogenes, tumor suppressor genes, or genes responsible for genetic diseases. The method detects different conformations adopted by partially denatured DNA fragments resulting from their specific nucleotide sequences under denaturing conditions. Denatured single-stranded DNA fragments are allowed to partially renature without formation of double-stranded DNA. The particular conformations adopted by each of the renatured fragments depend on each of their specific nucleotide sequences. The fragments are run on polyacrylamide gels to detect subtle changes in migration due to their particular secondary structures. Resulting fragment band in the gel will misalign if any point mutations are present to alter the conformation. 